\title{
Market Behavior for in Shell Brazil Nuts Produced in Brazil from 2000 to 2010
}

\author{
Elisangela Lobo Schirigatti ${ }^{1}$, Giovanna Paiva Aguiar ${ }^{1}$, \\ Joao Carlos Garzel Leodoro da Silva ${ }^{2}$, José Roberto Frega ${ }^{3}$, \\ Alexandre Nascimento de Almeida ${ }^{4}$, Vitor Afonso Hoeflich ${ }^{5}$ \\ ${ }^{1}$ Engenharia Florestal, Universidade Federal do Paraná - UFPR, Curitiba/PR, Brasil \\ ${ }^{2}$ Universidade Federal do Paraná - UFPR, Curitiba/PR, Brasil \\ ${ }^{3}$ Departamento de Administração Geral e Aplicada, Universidade Federal do Paraná - UFPR, Curitiba/PR, Brasil \\ ${ }^{4}$ Faculdade UnB de Planaltina, Universidade de Brasília - UnB, Brasília/DF, Brasil \\ ${ }^{5}$ Departamento de Economia Rural e Extensão, Universidade Federal do Paraná - UFPR, Curitiba/PR, Brasil
}

\begin{abstract}
This paper aimed to analyze the market behavior of in shell Brazil nuts produced by Brazil during the period of 2000 to 2010. In order to do it, structural brakes in the data were identified, the existence of correlations between the variables price, quantity and value was investigated; and the shift of the supply and demand curves was described for the nuts production. The trend model was used to identify the direction of the shift, by calculating the growth rates of national prices and of produced quantities. When analyzing the whole period (2000-2010), there was a positive shift of the demand curve, but when separately analyzing the two sub periods defined by the Chow test (2000-2005 and 2006-2010), a negative shift of the supply curve was identified on the first sub period, while the second subperiod revealed a positive shift of the supply curve. The results showed that the market of Brazil nuts is ascending and that the government's incentive policies to the activity were effective.
\end{abstract}

Keywords: forest economics, non-timber forest products, Brazil nuts.

\section{Comportamento do Mercado da Castanha-do-Brasil com Casca Produzida no Brasil de 2000 a 2010}

\section{RESUMO}

O objetivo do trabalho foi analisar o comportamento do mercado da castanha-do-Brasil com casca produzida pelo Brasil no período de 2000 a 2010. Para isso, identificaram-se quebras estruturais nas séries de dados utilizadas; investigou-se a existência de correlações entre as variáveis preço, quantidade e valor; e descreveram-se os deslocamentos das curvas de oferta e demanda da castanha-do-Brasil com casca produzida pelo país nesse período. O modelo de tendência foi utilizado para identificar a direção dos deslocamentos das curvas, por meio do cálculo das taxas de crescimento do preço pago ao coletor e da quantidade produzida. Para o período integral (2000-2010) houve deslocamento positivo da curva de demanda. Porém ao se analisar separadamente os subperíodos identificados pelo teste de Chow (2000-2005 e 2006-2010), verificou-se um deslocamento negativo da oferta no primeiro subperíodo e um deslocamento positivo da oferta no segundo subperíodo. Os resultados mostraram que o mercado de castanha-do-Brasil está crescendo e que as políticas de incentivo do governo à atividade foram efetivas.

Palavras-chave: economia florestal, produtos florestais não madeireiros, castanha-do-Brasil. 


\section{INTRODUCTION}

Extracted from the species Bertholletia excelsea H.B. $\&$ K., Brazil nuts occur naturally in the Amazon forest. The nuts are in fact the seeds of a tree commonly called "castanheira" and once taken out from their fruit, they can be sold in shell or can go through the process of being shelled (Müller et al., 1995). These nuts have a great environmental, social and economic importance to Brazil and to local populations that depend on them (Newing \& Harrop, 2000; Santos et al., 2003; Wadt et al., 2008). Brazil nuts' production is exclusively done in the extractive system (Nelson \& Fujiwara, 2002), since its monocultures are not economically viable so far (Pimentel et al., 2007).

According to Homma (1996), all extractive products tend to follow the same economic cycle, which consists on the phases of expansion, stabilization, decline and domestication. Moreover, the author says that Brazil nuts are reaching the stabilization phase, which is characterized by the equilibrium between supply and demand in a point close to the maximum possible capacity of extraction. In addition, he explains that incentives for a more efficient extraction of the product, or measures to protect the extraction process may be adopted at this moment, in order to delay the decline phase.

Although it isn't one of the main products exported by Brazil, or even by the northern region of the country, Brazil nuts have a great impact on the income of the communities that count on its extraction as one of their main economic activities (Santos, Sena \& Rocha, 2010). Some measures that can improve the life quality and income of these populations are the employment of adequate public policies, the organization of these communities into cooperative associations, training and raising their awareness about the market, and doing appropriate investments of public resources in their economic activity (Newing \& Harrop, 2000; Stoian, 2004; Silvertown, 2004).

That being said, Almeida et al. (2009b) highlight the importance of studies regarding the historical evolution of extractive products' markets. The authors say that these studies help the preparation of appropriate public policies that can benefit both the extractive communities and the local economy. This way, this paper is important to help public policy makers to understand the supply-demand dynamics of the Brazil nuts market and consequently improve public policies related to it.

Therefore, the aim of this paper is to analyze the market behavior of in shell Brazil nuts produced by Brazil, during the period of 2000 to 2010. In order to do it, the secondary aims of the study are to identify structural brakes on the data series; to verify the existence of correlations between the variables price, quantity and value; and to describe the shift of the supply and demand curves for the production of in shell Brazil nuts.

\section{MATERIAL AND METHODS}

\subsection{Theoretical reference}

According to Pindyck \& Rubinfeld (2002), the supply curve represents the rate between supplied quantity and price of a given product, and the demand curve shows the rate between demanded quantity and the price that the consumer is willing to pay for the product. The author also explains that while the supply curve is shifted according to changes in technology and in production costs, the demand curve's shift is due to income changes, consumer preference changes, and changes on the prices of substitute and complementary products.

Almeida et al. (2009a, b, c) explain that positive or negative changes on the growth rate of a product's price and quantity may either show a dominant shift in the supply or in the demand curve, as well as its direction. On Figure 1, the authors show that if the growth rates of both price and quantity have the same sign, the demand curve has been dominantly shifted. On the other hand, if they have different signs, it means a dominant shift of the supply curve (Figure 2).

Moreover, it is possible to see on Figure 1 the direction of the shift of the demand curve for each case. For instance, when both growth rates are positive, the curve is shifted to the right, and when both are negative, the shift happens to the left.

Finally, on Figure 2, the direction of the supply curve's shift is shown. When the quantity's growth rate is positive, and price's growth rate is negative, the supply curve is shifted to the right. On the other hand, 

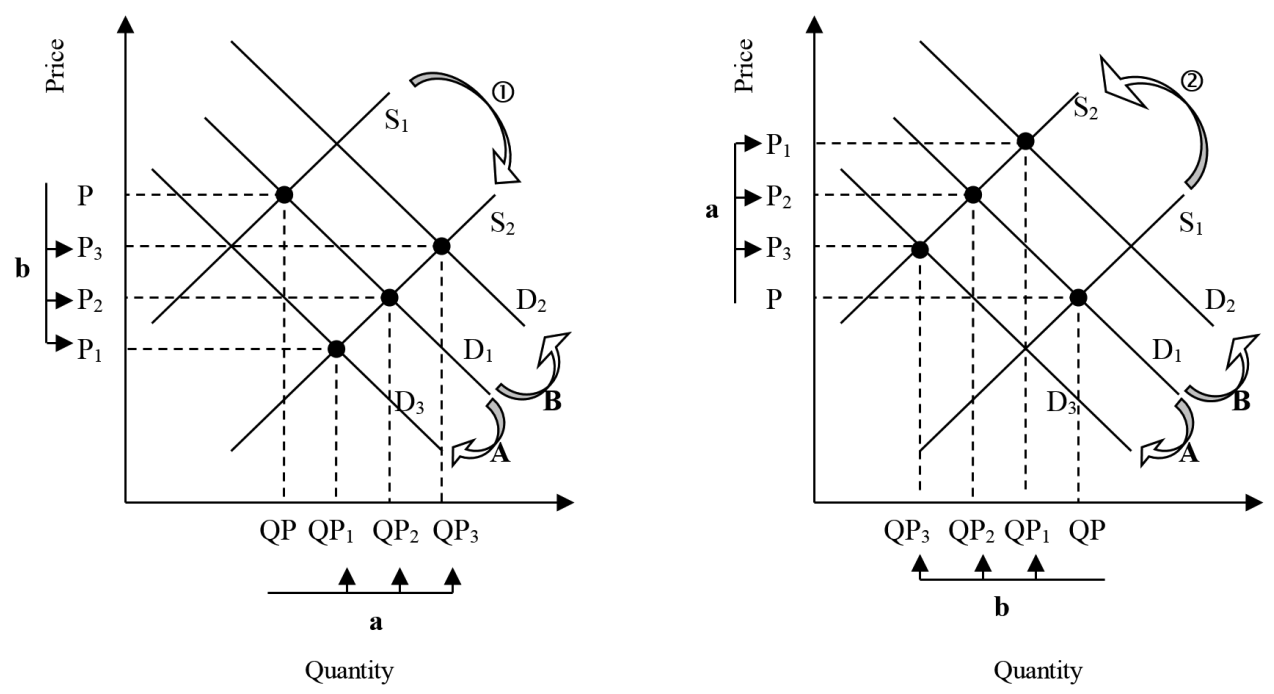

Figure 1. Dominant shift of the demand curve to the right and to the left according to the growth rates of both price and quantity. $\mathrm{D}=$ Demand; $\mathrm{S}=$ Supply.

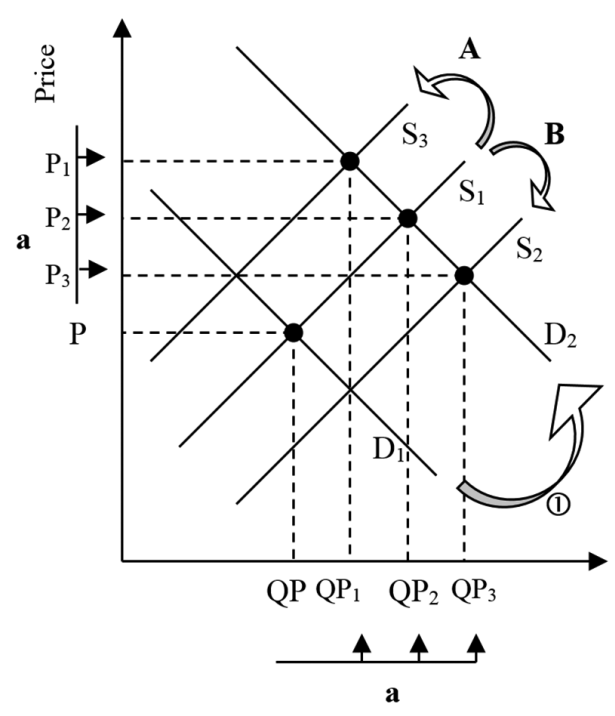

Quantity
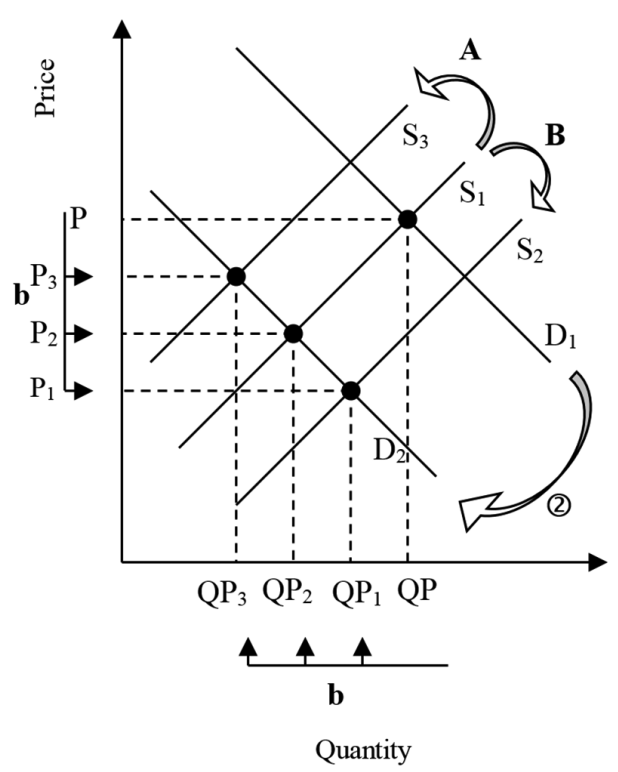

Figure 2. Dominant shift of the supply curve to the right and to the left according to the growth rates of both price and quantity. $\mathrm{D}=$ Demand; $\mathrm{S}$ = Supply.

when the quantity's growth rate is negative and the price's growth rate is positive, there is a shift to the left.

\subsection{Data}

Secondary data of produced quantity and value of the production (IBGE, 2012) of in shell Brazil nuts were collected annually from 2000 to 2010, a total of 11 years. The price data $(\mathrm{P})$ were obtained through the ratio between the variables value and quantity (Equation 1):

$$
P N=\frac{V P}{Q P}
$$

Where: $\mathrm{PN}=$ price paid to the producer $(\mathrm{R} \$ / \mathrm{kg})$

$\mathrm{VP}=$ production value $(\mathrm{R} \$)$

$\mathrm{QP}=$ produced quantity $(\mathrm{kg})$ 
The time series of prices and values was deflated with the Brazilian price index IPCA (Consumer Price Index - Índice de Preços ao Consumidor Amplo), considering 2010 as the base year and following the methodology of agricultural prices correction cited by Mendes \& Padilha (2007).

\subsection{Analytical reference}

\subsubsection{Structural stability of the data}

Gujarati (2006) says that when analyzing time series data, structural breaks in which the parameters of the model change in a given moment of the period may occur. If the break is not identified, the calculated trend model may not correctly represent the average behavior of the variable. Therefore, in order to test the structural stability of the data, the Chow test was applied according to the methodology described by Gujarati (2006) and with the aid of the software Gretl 1.9.9.

Furthermore, Gujarati (2006) explains that the Chow test assumes that there is homoscedasticity on the error terms of the subperiods' regressions. In other words, that they are distributed with the same variance: $\mathrm{u} 1 \mathrm{t} \sim \mathrm{N}(0, \sigma 2)$ and $\mathrm{u} 1 \mathrm{t} \sim \mathrm{N}(0, \sigma 2)$. The test also assumes that the error terms $\mu 1 \mathrm{t}$ and $\mu 2 \mathrm{t}$ have independent distributions.

Thus, after a visual analysis of the time series' graphs, possible structural breaks were identified. A model was proposed for each possible subperiod (Equations 2 and 3), as well as one for the whole period (Equation 4).

2000-2005: Yt $=\lambda 1+\lambda 2 \mathrm{Xt}+\mu 1 \mathrm{t} \mathrm{n} 1=6$

2006-2010: Yt $=\gamma 1+\gamma 2 \mathrm{Xt}+\mu 2 \mathrm{t} \mathrm{n} 2=5$

2000-2010: $Y t=\alpha 1+\alpha 2 X t+\mu 4 t n 4=(n 1+n 2)=11$

After that, the Ordinary Least Squares method (OLS) was employed to estimate the sum of squared residuals of the growth rate of the whole period (SQR1) and of the subperiods under evaluation (SQR2 and SQR3). After calculating their respective degrees of freedom $(\mathrm{n} 1-\mathrm{k}, \mathrm{n} 2-\mathrm{k}, \mathrm{n} 1+\mathrm{n} 2-2 \mathrm{k})$, the results were applied on Equation 5:

$$
F=\frac{S Q R_{5} / k}{S Q R_{4} /\left(n_{1}+n_{2}-2 k\right)} \sim F_{\left[k,\left(n_{1}+n_{2}-2 k\right)\right]}
$$

Where: SQR4 $=(\mathrm{SQR} 1+\mathrm{SQR} 2)$ and SQR5 $=(\mathrm{SQR} 3-\mathrm{SQR} 4)$
After applying the results on Equation 5, it was possible to decide whether to accept or to reject the Null Hypothesis (H0). The Null Hypothesis says that there aren't structural changes in the time series, since the parameters of the equation are stable according to the tabulated critical value $\mathrm{F}$, with a probability degree of 0.05 .

\subsubsection{Correlation analysis}

A correlation analysis was performed in order to verify if the variables production value $(R \$)$, produced quantity $(\mathrm{kg})$ and price received by the producer $(\mathrm{R} \$ / \mathrm{kg})$ are related. According to Field (2009), the correlation coefficient is the standardized covariance obtained by the Equation 6.

$r=\frac{\operatorname{cov}(x, y)}{S_{x} S_{y}}=\frac{\sum\left(x_{i}-\bar{x}\right)\left(y_{i}-\bar{y}\right)}{(N-1) S_{x} S_{y}}$

In the standardized covariance the coefficients are between -1 and +1 . When the coefficient is -1 , it means that the variables are perfectly and negatively correlated, which means that when one rises, the other is proportionally reduced. On the other hand, a coefficient of +1 indicates that when a variable raises the other also rises in the same proportion (Hair et al., 2009).

In order to interpret the results obtained by the correlation analysis, the Cohen criteria, presented by Pallant (2007) was used: Small (from \pm 0.10 to \pm 0.29 ), Medium (From \pm 0.30 to \pm 0.49 ), and High (From \pm 0.50 to \pm 1.00 ).

\subsubsection{Supply and demand shifts}

As in the studies of Almeida et al. (2009a e 2009b), the method for identifying the dominant shift and its direction is divided into two steps. On the first step, a linear trend analyzes was performed in order to determine the annual compound growth rates of the Brazilian production of Brazil nuts, during the period from 2000 to 2010 and the subperiods identified by the Chow test. Data of value, quantity and real price were used in order to do it. Afterwards, the second step consisted on using the trend analysis results for identifying which curve was dominantly shifted and the direction of the shift.

The methodology to obtain the estimates of the compound growth rates used the Ordinary Least Squares (OLS) method and was based in Gujarati (2006) and applied by Brasil (2006) and Almeida et al. 
(2009a, b). The OLS method adjusts a variable's linear trend in semilog equations, where the angular inclination coefficient $\beta_{1}$ measures the constant relative variation for a given absolute variation on the value of the $t$ regressor.

The growth rate calculus process follows the following logic: $Y_{t}=P_{t}$ (Brazil nut's price on the moment $t$ ) or $Y_{t}=Q_{t}$ (Produced quantity of Brazil nuts on the moment $t$ ) according to the Equation 7:

$Y_{t}=Y_{0}(1+r)^{T}$

Where: $Y_{t}=$ Price or quantity considering the rate $r$ over time $T ; Y_{0}=$ initial price or quantity; $r=$ compound rate; and $T=$ time period.

Equation 7 may be rewritten into Equation 8 by calculating its natural logarithm:

$\operatorname{Ln} Y_{t}=\ln Y_{0}+T \ln (1+r)$

If $\beta_{0}=\ln Y_{0^{\prime}} \beta_{1}=\ln (1+r)$ and adding the disturbance term $\mu$ t in the Equation 9, the following models are obtained:

$$
\begin{aligned}
& \ln Q t=\beta_{0}+\beta_{1} t+\mu_{t} \\
& \ln V t=\beta_{0}+\beta_{1} t+\mu_{t} \\
& \ln P R t=\beta_{0}+\beta_{1} t+\mu_{t}
\end{aligned}
$$

Where: $Q_{t}$ - Produced quantity of Brazil nuts on the year $t ; V_{t}$ - Produced value of Brazil nuts on the year $t$; $P R_{t}$ - Price received by the producer of Brazil nuts on the year $t ; t$ - Trend variable, measured in years; $\mu_{t}$ - Disturbance term.

The results obtained with these models were the instantaneous growth rates, which were then used to calculate the compound growth rates through Equation 10. According to Gujarati (2006), the compound rate is usually slightly higher than the instantaneous growth rate, an effect of the composition itself.

$$
r=\left[\left(\operatorname{anti} \log \beta_{1}-1\right) * 100\right]
$$

The analysis of the rate between the growth rate and the shifts in the supply and demand curves was oriented according to the economic theory in Pindyck \& Rubinfeld (2002). This rate was resumed by Almeida et al. (2009a), who described the shift according to the growth rate sign (Table 1).

In order to validate the results obtained by the supply and demand model, it is necessary to admit that the Brazil nut market is at least almost competitive (Pindyck \& Rubinfeld, 2002), cited by Almeida et al. (2009a), and to rule out the possibility that the price elasticity of the demand and of the supply are either completely elastic or inelastic.

\section{RESULTS AND DISCUSSION}

\subsection{Structural stability of the data}

The Chow test was used in order to test the structural stability of the data. For both value and price, the test did not find any brakes. However, it found a structural brake on the produced quantity data $(F(2,7)=7.05$, $\mathrm{p}<0.05)$ in 2005. This way, on Figure 3 it can be observed that until 2005 the data showed a falling trend while after that year it presented a growth trend.

Hill et al. (2003) and Gujarati (2006) explain that when a structural brake is found in the data series, the model estimators that predict the full period's growth trend, in this case from 2000 to 2010, may have dubious, biased and inconsistent values. Thus, the production market dynamics of in shell Brazil nuts will not only be analyzed on the full period, from 2000 to 2010 , but also on two subperiods, from 2000 to 2005 and from 2006 to 2010. Although the brake was found only for the produced quantity, in order to obtain a homogeneous analysis, the division into two subperiods was also used for the two other variables, value and price.

Table 1. Shifts of the supply and demand curves according to the growth rates' signs of both price and quantity.

\begin{tabular}{cll} 
Shift & Variation in the growth rates of quantity and price & Dominant shifts of the Demand and Supply curves \\
$\uparrow \mathrm{D}$ & Positive variation in quantity and price & Dominant shift of the Demand curve to the right \\
$\downarrow D$ & Negative variation in quantity and price & Dominant shift of the Demand curve to the left \\
$\uparrow S$ & Positive variation in quantity and negative variation in price & Dominant shift of the Supply curve to the right \\
$\downarrow S$ & Negative variation in quantity and positive variation in price & Dominant shift of the Supply curve to the left \\
$\uparrow D$ & Positive variation in quantity and price & Dominant shift of the Demand curve to the right \\
\hline
\end{tabular}

Source: adapted from Almeida et al. (2009a). 


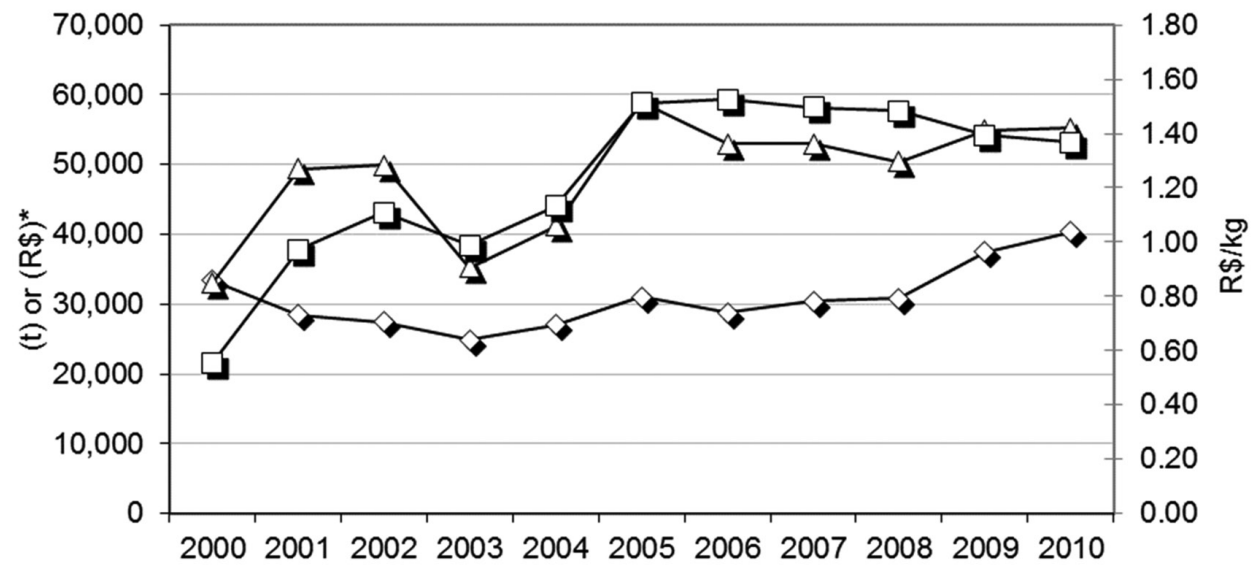

$\neg$ Quantity $\quad \rightarrow-$ Value $\quad-\square-$ Price

Figure 3. Evolution and trend lines of the produced quantity and of the price paid to the producer of Brazil nuts, between 2000 and 2010. ${ }^{*}$ The units are tons for the quantity time series and Brazilian Reais (R\$) for the value time series. Source: the authors using data from IBGE (2012).

\subsection{Market dynamics and correlation analysis}

In the period of 2000-2010, Brazil produced an average of 30.90 thousand tons of Brazil nuts per year, representing an average value of $\mathrm{R} \$ 48.60$ thousand per year, with an average price of $\mathrm{R} \$ 1.58 / \mathrm{kg}$. These corresponded to annual growth rates of $2.63 \%$ in quantity, $1.12 \%$ in price and $3.78 \%$ in value, as indicated in Table 2. The more representative growth in QGR than in PGR means that quantity contributed more to the value growth rate (VGR) than price did.

However, when analyzing each subperiod separately, different results can be found. The first subperiod (2000-2005) presented annual growth rates of $-1.78 \%$ in quantity, $7.80 \%$ in price and $5.88 \%$ in produced value (Table 2). The opposite signs in the values of QGR and PGR highlight that the produced value growth rate (VGR) on this subperiod was mainly affected by the price raise.

On the other hand, on the second subperiod (2006-2010), produced quantity, price and produced value had annual growth rates of $9.23 \%,-7.37 \%$ and $1.18 \%$ respectively. This result leads to the conclusion that in this case the main responsible for the produced value growth rate (VGR) was the growth of the produced quantity.

Finally, the correlation analysis of the variables price, quantity and value showed that there is a direct, high and significant rate between value and quantity $\left(r_{s}=0.582, p<0.10\right)$. It also revealed an inverse, high and significant rate between price and quantity only on the second subperiod $(r=-0.971, p<0.05)$.

\subsection{Supply and demand shifts}

After calculating the growth rates of both the produced quantity and the price paid to the producer, the supply and demand shifts and their directions were identified (Table 3).

Since it had a positive variation in both price and quantity, the full period of 2000-2010 presented a dominant shift in the demand curve to the right ( $\uparrow D)$. According to Almeida et al. (2009a), this shift characterizes an ascending market in the long term. However, when looking into both subperiods, the dominant shifts happened in the supply curve rather than in the demand curve, meaning a different behavior in the short term.

For instance, on the first subperiod (2000-2005) there was a positive variation on the price and a negative variation on the quantity, indicating a dominant shift of the supply curve to the left $(\downarrow S)$. This result is similar to the one found by Almeida et al. (2009a) when studying the Brazilian non-timber products market from 1982 to 2005 . The authors found a growth rate of $-2.08 \%$ per year in the quantity and of $2.51 \%$ per year in the price 
Table 2. Production value, produced quantity and price paid to the producer as well as their growth rates on the periods of 2000 to 2010,2000 to 2005 and 2006 to 2010 respectively.

\begin{tabular}{|c|c|c|c|c|c|c|c|c|c|}
\hline Year & $\begin{array}{l}\text { Value } \\
\text { (R\$) }\end{array}$ & $\begin{array}{l}\text { VGR } \\
(\%)^{*}\end{array}$ & $\begin{array}{l}\text { VGR } \\
(\%)^{\star *}\end{array}$ & $\begin{array}{c}\text { Quant. } \\
\text { (kg) }\end{array}$ & $\begin{array}{l}\text { QGR } \\
(\%)^{*}\end{array}$ & $\begin{array}{l}\text { QGR } \\
(\%)^{* *}\end{array}$ & $\begin{array}{c}\text { Price } \\
\text { (R\$/ kg) }\end{array}$ & $\begin{array}{l}\text { PGR } \\
(\%)^{\star}\end{array}$ & $\begin{array}{l}\text { PGR } \\
(\%)^{* *}\end{array}$ \\
\hline 2000 & 33,062 & \multirow{11}{*}{3.78} & & 33,431 & \multirow{11}{*}{2.63} & & 0.99 & \multirow{11}{*}{1.12} & \\
\hline 2001 & 49,345 & & & 28,467 & & & 1.73 & & \\
\hline 2002 & 49,910 & & 5.88 & 27,389 & & -1.78 & 1.82 & & 7.80 \\
\hline 2003 & 35,213 & & & 24,894 & & & 1.41 & & \\
\hline 2004 & 41,194 & & & 27,059 & & & 1.52 & & \\
\hline 2005 & 58,919 & & & 30,975 & & & 1.90 & & \\
\hline 2006 & 52,983 & & & 28,806 & & & 1.84 & & \\
\hline 2007 & 52,966 & & 1.18 & 30,406 & & 9.23 & 1.74 & & -7.37 \\
\hline 2008 & 50,384 & & & 30,815 & & & 1.64 & & \\
\hline 2009 & 54,894 & & & 37,467 & & & 1.47 & & \\
\hline 2010 & 55,194 & & & 40,357 & & & 1.37 & & \\
\hline
\end{tabular}

Source: elaborated by the authors with data from IBGE (2012). Note: GR= Annual growth rate of V=Value; Q=Quantity; and P=Price. ${ }^{*}$ Full period $(2000-2010) .{ }^{* *}$ Subperiods $(2000-2005 ; 2006-2010)$.

Table 3. Shifts of the supply and demand curves according to the variations in the growth rates of the produced quantity and the price paid to the producer, in the full period of 2000-2010 and in the subperiods of 2000-2005 and 2006-2010.

\begin{tabular}{|c|c|c|}
\hline \multicolumn{3}{|c|}{ Production } \\
\hline & Variations of the growth rates & Dominant shift \\
\hline 2000-2010 & Positive variation in quantity and price. & $\uparrow \mathrm{D}$ \\
\hline 2000-2005 & Positive variation in price and negative variation in quantity. & $\downarrow S$ \\
\hline 2006-2010 & Positive variation in quantity and negative variation in price. & $\uparrow S$ \\
\hline
\end{tabular}

Source: elaborated by the authors.

of the Brazil nuts produced in Brazil, also indicating a dominant shift of the supply to the left $(\downarrow S)$.

Based on Lafleur (1993) and Almeida et al. (2009a) the supply shift on that period might have had two causes. It might have been related to the increasing costs for the extraction of nuts or to a reduction in the number of nut collectors, due to either the great difficulties of the job or to the migration of labor force to other economic activities. Moreover, Almeida et al. (2009a) explained that contrary to a curve's shift to the right, which characterizes an ascending market in the long term, a curve's shift to the left indicates a reduction in the economic activity of the sector being studied.

Similarly, Pennacchio (2006) explains that the reduction of the Brazilian nuts' production, especially in 2003, can be explained by a crop shortfall that happened that year, and by the deforestation of the Amazon forest for pasture formation, which reduces the number of available productive Brazil nut trees. Ângelo et al. (2013a) reinforced that deforestation causes depredation of the Brazil nut trees, which implies in a social cost to the society. Additionally, Ângelo et al. (2013b) found in their study that deforestation affects the production of Brazil nuts, which, according to them, suggests some inefficiency of the law 6.462/1992 of the state of Pará, designed to protect the specie from being cut down.

As for the second subperiod (2006-2010), the positive variation in the quantity and the negative variation in the price indicate a dominant shift of the supply curve to left ( $\uparrow \mathrm{S}$ ). Contrary to the previous subperiod, this shift suggests an increase of the product's supply, which is usually explained either by an improvement in technology or by a rise in productivity (Almeida et al., 2009a). However, as Brazil nuts are exclusively extractive, improvements in technology can't explain the rise of its supply.

A different possible explanation for the shift of the supply curve to the right is the implementation of government incentive policies to the extractive activities, such as the Anticipated Acquisition of the Production of Extractive Families Program. This program is part of 
wider one called Food Acquisition Program, developed by the Brazilian National Food Supply Company (CONAB), and implemented in January of 2004 (Brasil, 2013). When collectors are faced with the guarantee that their production will be bought for a competitive price, it is expected that they will feel encouraged to collect more nuts and stay in the activity.

Finally, an important observation about the supply and demand shifts here described is that although the complete period (2000-2010) presented a demand shift, both subperiods (2000-2005 and 2006-2010) presented supply shifts. This happened because when observing the full period, both price and quantity curves have a positive growth tendency, even if their values oscillate throughout the years. However, when we focus on each subperiod determined by the Chow test, the growth tendency is not necessarily the same for both variables, indicating shifts in the supply curves when one is positive and the other is negative.

\section{CONCLUSION}

The market of Brazil nuts grew consistently from 2000 to 2010 . This growth can be mainly explained by an increase of the production instead of the product's price. In order to diminish the volatility of the price in this market, public policies should include strategies of value aggregation, avoiding the market's growth to depend solely on an increase in production.

On the long run, factors related to the demand predominantly influenced the market. However, on the short run, factors related do the supply influenced the market the most. The demand shift to the right in the full period, and the supply shift to the right during the most recent subperiod showed that the market of Brazil nuts is ascending and that the government's incentive policies to the activity were effective.

\section{SUBMISSION STATUS}

Received: 28 jan., 2014

Accepted: 10 feb., 2016

\section{CORRESPONDENCE TO}

\section{Giovanna Paiva Aguiar}

Laboratório de Economia Florestal, Centro de Ciências Florestais e da Madeira - CIFLOMA,
Universidade Federal do Paraná - UFPR, Campus III, Av. Pref. Lothário Meissner, 632, Jardim Botânico, CEP 80210-170, Curitiba, PR, Brasil

e-mail: giovanna.paguiar@gmail.com

\section{REFERENCES}

Almeida AN, Bittencourt AM, Santos AJ, Eisfeld CL, Souza VS. Evolução da produção e preço dos principais produtos florestais não madeireiros extrativos do Brasil. Cerne 2009a; 15(3): 282-287.

Almeida AN, Santos AJ, Silva JCGL, Bittencourt AM. Análise do mercado dos principais produtos não-madeiráveis do estado do Paraná. Floresta 2009b; 39(4): 753-763. http:// dx.doi.org/10.5380/rf.v39i4.16310.

Almeida AN, Silva JCGL, Ângelo H, Bittencourt AM, Nuñez BEC. Mercado paranaense de madeira em tora procedente de silvicultura entre 1999 e 2005. Floresta 2009c; 39(4): 869-875. http://dx.doi.org/10.5380/rf.v39i4.16322.

Ângelo H, Almeida AN, Calderon RA, Pompermayer RS, Souza AN. Determinantes do preço da castanha-do-Brasil. Scientia Forestalis 2013a; 41(98): 195-203.

Ângelo H, Pompermayer RS, Almeida AN, Moreira JMMAP. O custo social do desmatamento na Amazônia brasileira: o caso da castanha-do-brasil (Bertholletia excelsa). Ciência Florestal 2013b; 23(1): 183-191. http:// dx.doi.org/10.5902/198050988452.

Brasil AA. As exportações brasileiras de painéis de madeira [dissertation]. Curitiba: Universidade Federal do Paraná; 2006.

Brasil. Ministério do Desenvolvimento Agrário - MDA. Programa de aquisição de alimentos [online]. Brasília: MDA; 2013 [cited 2013 Sept. 30]. Available from: http:// www.mda.gov.br/portal/saf/programas/paa

Field A. Descobrindo a estatística usando o SPSS. 2nd ed. Porto Alegre: The Art of Medication; 2009.

Gujarati D. Econometria básica. 4th ed. Rio de Janeiro: Elsevier; 2006.

Hair JF, Tatham RL, Anderson RE, Black W. Análise multivariada dos dados. 6th ed. São Paulo: The Bookman; 2009.

Hill RC, Griffiths WE, Judge GG. Econometria. 2nd ed. São Paulo: Saraiva; 2003.

Homma AKO. Modernization and technological dualism in the extractive economy in Amazonia. In: Pérez MR, Arnorld JEM, editors. Current issues in non-timber forest products research. Bogor: Center for International Forestry Research; 1996.

Instituto Brasileiro de Geografia e Estatística - IBGE. Produção da extração vegetal e da silvicultura [online]. Rio de Janeiro: IBGE; 2012 [cited 2012 Mar. 22]. Available 
from: http://www.sidra.ibge.gov.br/bda/tabela/protabl. asp? $\mathrm{c}=290 \& \mathrm{z}=\mathrm{p} \& \mathrm{o}=29 \& \mathrm{i}=\mathrm{P}$.

Lafleur JR. O mercado de castanha do pará no Brasil: Projeto castanha. Recife: ECOTEC; 1993.

Mendes JTG, Padilha JB Jr. Agronegócio: uma abordagem econômica. São Paulo: Pearson Prentice Hall; 2007.

Müller CH, Figueiredo FJC, Kato AK, Carvalho JEU, Stein RLB, Silva AB. A cultura de Castanha-do-Brasil. Brasília: EMBRAPA-SPI; 1995.

Nelson D, Fujiwara L. Projeto Castanha-do-Brasil. In: Barbosa HB, Spink P. 20 Experiências de gestão pública e cidadania. São Paulo: Programa Gestão Pública e Cidadania; 2002.

Newing H, Harrop S. European health regulations and Brazil nuts: implications for biodiversity conservation and sustainable rural livelihoods in the Amazon. Journal of International Wildlife Law and Policy 2000; 3(2): 109-124. http://dx.doi.org/10.1080/13880290009353951.

Pallant J. SPSS survival manual. New York: McGraw Hill; 2007.

Pennacchio HL. Proposta de preço mínimo: Castanha-doBrasil: Safra 2006/2007. Brasília: CONAB; 2006.

Pimentel LD, Wagner A Jr, Santos CEM, Bruckner CH. Estimativa de viabilidade econômica no cultivo da Castanhado-Brasil. Informações Econômicas 2007; 37(6): 26-36.
Pindyck RS, Rubinfeld DL. Microeconomia. São Paulo: Prentice Hall; 2002.

Santos AJ, Hildebrand E, Pacheco CHP, Pires PTL, Rochadelli R. Produtos não madeireiros: conceituação, classificação, valoração e mercados. Revista Floresta 2003; 33(2): 215-224.

Santos JC, Sena ALS, Rocha CIL. Competitividade brasileira no comércio internacional de castanha-dobrasil. In: Anais do $48^{\circ}$ Congresso Brasileiro da SOBER; 2010; Campo Grande. Brasília: SOBER; 2010. p. 1-14.

Silvertown J. Sustainability in a nutshell. Trends in Technology and Evolution 2004; 19(6): 276-278.

Stoian D. Cosechando lo que cae: la economía de la castana (Bertholletia excelsa H.B.K.) en la Amazonía boliviana. In: Alexiades MN, Shanley P, editors. Productos forestales, medios de subsistencia y conservación. Estudios de caso sobre sistemas de manejo de productos forestales no maderables. Bogor: CIFOR; 2004. p. 89-116, vol. 3.

Wadt LHO, Kainer KA, Staudhammer CL, Serrano ROP. Sustainable forest use in Brazilian extractive reserves: Natural regeneration of Brazil nut in exploited populations. Biological Conservation 2008; 141(1): 332-346. http:// dx.doi.org/10.1016/j.biocon.2007.10.007. 